\title{
A Multiplex PCR System for the Specific Detection of Cylindrocarpon liriodendri, C. macrodidymum, and C. pauciseptatum from Grapevine
}

\author{
Sandra Alaniz, Josep Armengol, José García-Jiménez, Paloma Abad-Campos, and Maela León, Instituto Agro- \\ forestal Mediterráneo, Universidad Politécnica de Valencia, Camino de Vera s/n, 46022-Valencia, Spain
}

\begin{abstract}
Alaniz, S., Armengol, J., García-Jiménez, J., Abad-Campos, P., and León, M. 2009. A multiplex PCR system for the specific detection of Cylindrocarpon liriodendri, C. macrodidymum, and $C$. pauciseptatum from grapevine. Plant Dis. 93:821-825.

Cylindrocarpon liriodendri and C. macrodidymum are the causal agents of grapevine black foot disease. Recently, a third species, C. pauciseptatum, has been isolated from roots of grapevine showing decline symptoms. Currently, reliable identification of isolates of these species through phenotypical characteristics has not been possible. The polymerase chain reaction (PCR)-based method developed in this study allows a quick and easy detection of Cylindrocarpon spp. associated with grapevine. Three primer pairs annealing to variable, partly species-specific sites of the internal transcribed spacer regions amplified species-specific PCR fragments of different sizes in C. liriodendri, C. macrodidymum, and C. pauciseptatum in a multiplex assay with DNA obtained with both quick and traditional extraction methods. They did not generate any PCR product in other fungal trunk pathogens or contaminants commonly associated with grapevines. When universal fungal ITS primers were used in a nested multiplex PCR, the three primer pairs also detected C. liriodendri, C. macrodidymum, and C. pauciseptatum in total DNA extracted from roots of inoculated grapevines. The designed methods can be used for the diagnosis of these fungi from pure culture or infected grapevines.
\end{abstract}

Black foot disease caused by Cylindrocarpon spp. is a severe disease of grapevines in nurseries and young vineyards (11). It was first described in 1961 (16), and over the last decade, its incidence has been reported in different grapevinegrowing areas around the world $(2,11,12$, 22,25).

Vines affected by black foot disease show sunken necrotic root lesions and a reduction of root biomass. Removal of rootstock bark reveals black discoloration and necrosis of wood tissues which develops from the base of the rootstock. Other symptoms include reduced vigor, shortened internodes, sparse foliage, and small leaves with interveinal chlorosis and necrosis, frequently leading to the death of the plants $(9-11,16,25,28)$.

In recent years, a large number of Cylindrocarpon or Cylindrocarpon-like species have been described from grapevines showing black foot disease symptoms $(7,12,25,27,28)$, but mainly two species, $C$.

Corresponding author: S. Alaniz

E-mail: salaniz@fagro.edu.uy

Current address of S. Alaniz: Departamento de Protección Vegetal, Facultad de Agronomía, Universidad de la República, Garzón 780, CO 12900, Montevideo, Uruguay.

Accepted for publication 27 April 2009.

doi:10.1094/PDIS-93-8-0821

(C) 2009 The American Phytopathological Society liriodendri J.D. MacDonald \& E.E. Butler and $C$. macrodidymum Schroers, Halleen $\&$ Crous, were identified as the causal agents of this disease $(12,13)$. Recently, Schroers et al. (29) described a third Cylindrocarpon species associated with grapevine, C. pauciseptatum Schroers \& Crous. This species was isolated from roots of grapevine showing decline symptoms, including symptoms of black foot disease, in Slovenia and New Zealand. However, its pathogenicity to grapevine was not confirmed by these authors.

The identification of these Cylindrocarpon species through phenotypical characteristics is not straightforward. Colony colors and textures, conidial dimensions, and amounts of sporulation are heterogeneous. Within a given Cylindrocarpon species, isolates have variable phenotypes and the range of these phenotypic characters overlap between species $(2,12,22,24)$. Consequently, it has not been possible to establish a reliable correspondence among these variables and the description of species. Halleen et al. (12) used the size of macroconidia to separate $C$. macrodidymum from $C$. liriodendri, indicating that the first produces larger and wider macroconidia than the second. Petit and Gubler (22) commented that it is possible to differentiate $C$. liriodendri from $C$. macrodidymum on the basis of reverse color on $2 \%$ malt extract agar (MEA); C. liriodendri isolates had a buff reverse, whereas $C$. macrodidymum isolates had an orangedark brown reverse. However, Alaniz et al.
(2) concluded that these characteristics were not useful for species identification because macroconidia size overlap, and although both types of colors were observed when Cylindrocarpon spp. were grown on $2 \%$ MEA, they did not correspond with the species identification. These authors identified both species into a collection of 82 isolates because they subjected phenotypical data to a multivariate factorial analysis. Thus, genotyping is the only reliable method for categorizing individual Cylindrocarpon isolates from grapevine at the species level $(2,12,22,29)$.

The development of species-specific primers has provided a powerful tool for the detection of plant pathogens. The identification of fungal pathogens based on polymerase chain reaction (PCR) using species-specific primers is now widely used, especially for economically important plant pathogens such as quarantinelisted fungi or those that are difficult to isolate or cause symptomless infections $(4,15,17,18,21,23)$. The internal transcribed spacer regions (ITS1 and ITS2) within the nuclear ribosomal gene clusters are particularly attractive loci for the design of PCR-based detection assays since they are readily accessible using universal primers (31) typically present in high copy number increasing PCR sensitivity and often exhibiting sufficient interspecific sequence divergence for the design of species-specific primers (20).

Among the different PCR techniques, the multiplex PCR utilizes within a single reaction several primer pairs, each of which may generate an amplicon with a specific size segregable from others easily through electrophoresis (5). This technique has been used extensively in plant pathology and permits the identification of more than one fungus in a unique reaction. The nested PCR includes a two-step system in which the first round PCR product is subjected to a second round PCR amplification with more specific primers. This technique is extremely sensitive and allows the detection of fungal pathogens in minute amounts of infected material (26).

The purposes of the current study were to (i) develop species-specific primers for the identification of C. liriodendri, C. macrodidymum, and $C$. pauciseptatum strains from grapevine, (ii) adjust the use of these primers in a multiplex PCR, and (iii) evaluate a nested multiplex PCR for the detection of $C$. liriodendri, C. macrodidy- 
mum, and C. pauciseptatum from inoculated grapevines.

\section{MATERIALS AND METHODS}

Fungal isolates. Twenty six isolates of C. liriodendri and 56 isolates of C. macrodidymum from roots or the basal end of rootstocks from grapevines exhibiting symptoms of black foot disease in Spain (2) and six isolates of C. pauciseptatum obtained from roots of grapevines in Slovenia (KIS 10763, KIS 10775, KIS 10778, KIS 10780, KIS 10798, and KIS 10799) (29) were used in the current study.

Additionally, reference isolates of $C$. liriodendri (CBS 117526, CBS 117640, Cy13 Portugal, and Cy15 Portugal, all from Portugal), C. macrodidymum (CBS 112609 from Australia), and C. pauciseptatum (CBS 120171, CBS 120172, and CBS 120173, all from Slovenia) were obtained from the collection of the Centraalbureau voor Schimmelcultures (CBS), Utrecht, the Netherlands and from the Laboratório de Patologia Vegetal "Veríssimo de Almeida", Lisboa, Portugal. Single-spored isolates were stored in $15 \%$ glycerol solution at $-80^{\circ} \mathrm{C}$ in $1.5-\mathrm{ml}$ cryovials.

DNA extractions. Two methods were used for fungal DNA extraction. In the first method, fungal mycelium and conidia from pure cultures, grown on one potato dextrose agar (PDA) (Biokar Diagnostics, Beauvais, France) petri dish for 2 weeks at $25^{\circ} \mathrm{C}$ in the dark, were scraped and mechanically disrupted by grinding to a fine powder under liquid nitrogen using a mortar and pestle. Total DNA was extracted with the E.Z.N.A. Plant Miniprep Kit (Omega Bio-tek, Norcross, GA) following the manufacturer's instructions. DNA was visualized under UV light on $0.7 \%$ (wt/vol) agarose gels stained with ethidium bromide and stored at $-20^{\circ} \mathrm{C}$. The second protocol used a quick DNA extraction method slightly modified from that of Collado-Romero et al. (3). A small amount of mycelium scraped with a sterile tip from colonies grown on PDA for 1 week at $25^{\circ} \mathrm{C}$ were disrupted in $20 \mu \mathrm{l}$ of $25 \mathrm{mM} \mathrm{NaOH}$, $\mathrm{pH} \mathrm{12,} \mathrm{in} \mathrm{0.2-ml} \mathrm{PCR} \mathrm{tubes.} \mathrm{These} \mathrm{solu-}$ tions were incubated for $15 \mathrm{~min}$ at $100^{\circ} \mathrm{C}$ and $5 \mathrm{~min}$ at $4^{\circ} \mathrm{C}$ in a thermocycler and 20 $\mu \mathrm{l}$ of $40 \mathrm{mM}$ Tris-HCl, pH 5, was added afterward. Of this lysate, $5 \mu \mathrm{l}$ was used directly for PCR assays.

Species-specific primers design. The ITS rDNA region, including ITS1, 5.8S, and ITS2, was amplified in 10 isolates of C. liriodendri and 30 isolates of C. macrodidymum selected from different geographic origins (2) using the universal primers ITS1/ITS4 (31). Each PCR reaction contained $1 \times$ PCR buffer, $2.5 \mathrm{mM}$ $\mathrm{MgCl}_{2}, 200 \mu \mathrm{M}$ of each dNTP, $0.2 \mu \mathrm{M}$ of each primer, $0.7 \mathrm{U}$ of Netzyme DNA polymerase (N.E.E.D. S.L., Valencia, Spain), and $1 \mu \mathrm{l}$ of template DNA. The PCR reaction mix was adjusted to a final volume of $25 \mu$ with water (Chromasolv Plus; Sigma-Aldrich, Steinheim, Germany).

PCR amplifications were performed on a Peltier Thermal Cycler-200 (MJ Research, Waltham, MA). The program consisted of an initial step of $3 \mathrm{~min}$ at $94^{\circ} \mathrm{C}$, followed by 35 cycles of denaturation at $94^{\circ} \mathrm{C}$ for $30 \mathrm{~s}$, annealing at $55^{\circ} \mathrm{C}$ for $30 \mathrm{~s}$, and elongation at $72^{\circ} \mathrm{C}$ for $1 \mathrm{~min}$. A final extension was performed at $72^{\circ} \mathrm{C}$ for 10 min. PCR products were analyzed in $1.5 \%$ agarose gels (agarose D-1 Low EEO; Conda, Madrid, Spain), stained with ethidium bromide and visualized under UV light. Gene Ruler 100-bp DNA ladder plus was used as a molecular weight marker (Fermentas Life Science, LeonRot, Germany).

PCR products were purified with the High Pure PCR Product Purification Kit (Roche Diagnostics, Mannheim, Germany) and sequenced in both directions by the DNA Sequencing Service of the Universidad Politécnica de Valencia-CSIC, Spain. Sequences were edited by the DNAman program (Version 4.03; Lynnon BioSoft, Pointe-Claire, Quebec, Canada) and aligned by the CLUSTAL W program (30). Nine sequences of $C$. pauciseptatum, corresponding to the isolates listed before, and additional sequences of $C$. liriodendri (AY677268, AY997532, AY997533, AY997544, AY997547, and DQ178163), C. macrodidymum (AY997549, AY997550, AY997554, AY997556, and EF607091), C. pausiceptatum (EF607080 and EF607090), and related fungi (AF220968, AF220969, AF220970, AY295318, AY295320, AY295322, AY295324, AY295333, AY677272, AY677273, AY677292, EF607079, DQ093765, and DQ779782), all obtained from the National Center for Biotechnology Information (NCBI) (Bethesda, MD), were added to the alignment. Species-specific primers were designed on the basis of the DNA sequence variability among the three Cylindrocarpon species and related fungi (Table 1). The character-

Table 1. Specific primers and expected product sizes of three Cylindrocarpon species

\begin{tabular}{|c|c|c|c|}
\hline Species & Primers $^{a}$ & Sequence $\left(5^{\prime}-3^{\prime}\right)$ & Product size (bp) \\
\hline \multirow[t]{2}{*}{ C. liriodendri } & Lir1 & СССТTGATTTTTATAACAGTATC & \multirow{2}{*}{253} \\
\hline & Lir2 & GAGGGCTCGCCGATCT & \\
\hline \multirow{2}{*}{ C. macrodidymum } & Mac1 & СССТGATTACATTTAAGAAGT & \multirow[b]{2}{*}{387} \\
\hline & $\mathrm{MaPa} 2$ & TGATCCGAGGTCAAACG & \\
\hline \multirow[t]{2}{*}{ C. pauciseptatum } & Pau1 & CTAAATTTAGTGGCGGTCA & \multirow[b]{2}{*}{117} \\
\hline & $\mathrm{MaPa} 2$ & TGATCCGAGGTCAAACG & \\
\hline
\end{tabular}

a $1=$ Forward and $2=$ reverse.

istics of each primer were evaluated by the DNAman program and were synthesized by Isogen Life Science (Utrecht, the Netherlands).

Assessment of primers specificity and sensitivity. The specificity of the designed primers was tested on all $C$. liriodendri, $C$. macrodidymum, and $C$. pauciseptatum DNA templates including reference isolates in a multiplex PCR. Additionally, fungal isolates of other trunk diseases of grapevine (Campylocarpon fasciculare CBS 113554, Campylocarpon pseudofasciculare CBS 112679, Phaeomoniella chlamydospora, Phaeoacremonium aleophilum, $P$. inflatipes, $P$. mortoniae, $P$. parasiticum, $P$. scolyti, Diplodia seriata, Fusicoccum aesculi, Neofusicoccum parvum, Eutypa lata, Fomitiporia mediterranea, and Stereum hirsutum) and contaminants commonly found in the process of fungal isolation from grapevines (Alternaria alternata, Cladosporium sp., Fusarium oxysporum and Penicillium digitatum) were included in the analyses. Total DNA from these fungi was extracted with the E.Z.N.A. Plant Miniprep Kit as described before.

Each PCR reaction contained 1× PCR buffer, $2.0 \mathrm{mM} \mathrm{MgCl}_{2}, 80 \mu \mathrm{M}$ of each dNTP, $0.2 \mu \mathrm{M}$ of each primer, $0.7 \mathrm{U}$ of Netzyme DNA polymerase, and $1 \mu \mathrm{l}$ of template DNA. The PCR reaction mix was adjusted to a final volume of $25 \mu \mathrm{l}$ with water. The program consisted of an initial step of $3 \mathrm{~min}$ at $94^{\circ} \mathrm{C}$, followed by $30 \mathrm{cy}-$ cles of denaturation at $94^{\circ} \mathrm{C}$ for $30 \mathrm{~s}$, annealing at $54^{\circ} \mathrm{C}$ for $30 \mathrm{~s}$, and elongation at $72^{\circ} \mathrm{C}$ for $45 \mathrm{~s}$. A final extension was performed at $72^{\circ} \mathrm{C}$ for $10 \mathrm{~min}$. The universal fungal primers, ITS1-F and ITS4, (8) were also used following the same conditions previously indicated to evaluate the efficiency of fungal DNA extraction, thus avoiding possible false negatives because of either undetectable DNA quantities or PCR inhibitory compounds.

To determine the detection limit of each pair of species-specific primers, DNA template of the three species of Cylindrocarpon were used for serial dilutions and subjected to multiplex PCR analyses as described above. The initial DNA concentration was quantified spectrophotometrically (DyNA quant 200; Hoefer Inc., Holliston, MA) and the dilutions were prepared with water (Chromasolv Plus) to yield final concentrations from $100 \mathrm{ng} \mathrm{\mu l}^{-1}$ to $10 \mathrm{fg}^{-1} \mathrm{l}^{-1}$ of DNA template; $1 \mu \mathrm{l}$ was used in each reaction.

Detection of C. liriodendri, C. macrodidymum, and $C$. pauciseptatum from inoculated plants by nested multiplex PCR. C. liriodendri isolate Cy 36, C. macrodidymum isolate Cy 96 (2), and C. pauciseptatum isolate CBS 120173 (29) were grown on PDA for 3 weeks at $25^{\circ} \mathrm{C}$ prior to inoculation. Inoculum was prepared for each isolate by flooding the agar surface with $10 \mathrm{ml}$ of sterile distilled water (SDW) 
and scraping with a spatula. The resulting spore suspension was filtered through two layers of cheesecloth. The filtrate was diluted with SDW and conidial concentration was adjusted with a hemacytometer and added to the sterilized peat to a final concentration of $5 \times 10^{5}$ conidia $\mathrm{g}^{-1}$ of sterilized peat. Ten cuttings of rootstock cv. $110 \mathrm{R}$ were planted individually in 220$\mathrm{cm}^{3}$ plastic pots containing inoculated sterilized peat, and control cuttings were planted in noninoculated sterilized peat as controls. All rootstock cuttings were covered with plastic bags and incubated at $25^{\circ} \mathrm{C}$ in darkness to promote callusing and root development. After 1 month, all plants were gently uprooted and washed free of soil. Total DNA was extracted from $0.2 \mathrm{~g}$ of necrotic roots with the E.Z.N.A. Plant Miniprep Kit as described before for fungal DNA extraction. A nested PCR combined with a multiplex PCR approach was used for the detection of both pathogens from infected plants. The first PCR reaction was carried out with primers ITS1F/ITS4 (8) containing $1 \times$ PCR buffer, $1.25 \mathrm{mM} \mathrm{MgCl} 2,80 \mu \mathrm{M}$ of each dNTP, 0.2 $\mu \mathrm{M}$ of each primer, $0.7 \mathrm{U}$ of Netzyme DNA polymerase, and $1 \mu \mathrm{l}$ of 1:100 dilution of template DNA. The PCR reaction mix was adjusted to a final volume of $25 \mu \mathrm{l}$ with water. The program consisted of an initial step of $3 \mathrm{~min}$ at $94^{\circ} \mathrm{C}$, followed by 35 cycles of denaturation at $94^{\circ} \mathrm{C}$ for $30 \mathrm{~s}$, annealing at $55^{\circ} \mathrm{C}$ for $30 \mathrm{~s}$, and elongation at $72^{\circ} \mathrm{C}$ for $45 \mathrm{~s}$. A final extension was performed at $72^{\circ} \mathrm{C}$ for $10 \mathrm{~min}$. PCR product was diluted 1:100 and $1 \mu \mathrm{l}$ was used as template DNA for the secondary PCR using species-specific primers to amplify $C$. liriodendri, $C$. macrodidymum, and $C$. pauciseptatum. PCR reaction was carried out as described before.

\section{RESULTS}

Species-specific primers design. Complete homogeneity of the ITS regions was observed within each of the C. liriodendri, C. macrodidymum, and C. pauciseptatum species studied and also in the additional sequences of these species and related fungi obtained from the NCBI. The comparison of sequences indicated that $C$. pauciseptatum is indeed closely related to C. macrodidymum, but sufficiently different to develop one specific primer in each one. On the basis of ITS regions polymorphic among species but conserved within each Cylindrocarpon species, five specific primers from 16 to $23 \mathrm{bp}$ were designed to amplify the three Cylindrocarpon species from grapevine (Table 1). Forward primers, Mac1 and Pau1, were designed to be used in combination with the reverse primer, $\mathrm{MaPa} 2$, to allow the amplification of fragments of different sizes in C. macrodidymum and C. pauciseptatum (Fig. 1).

Assessment of primers specificity and sensitivity. The multiplex PCR amplified all Cylindrocarpon isolates generating the predicted size in each species. We amplified in all isolates of $C$. liriodendri a unique fragment of DNA of $253 \mathrm{bp}$, in all C. macrodidymum isolates, a fragment of $387 \mathrm{bp}$, and in all C. pauciseptatum isolates, a fragment of $117 \mathrm{bp}$. No amplified products were generated from samples of other fungal trunk disease pathogens of grapevine or contaminants commonly found in the process of isolation (Fig. 2). All Cylindrocarpon isolates were amplified by template DNA obtained with both conventional and quick methods of DNA extraction.
The detection limit of the different pairs of species-specific primers ranged from $100 \mathrm{pg}$ to $100 \mathrm{fg}$ depending on the Cylindrocarpon species. The sensitivity of the primer sets enabled reliable detection of $C$. macrodidymum DNA as low as $100 \mathrm{fg}$ (Mac1/MaPa2), whereas for $C$. liriodendri and $C$. pauciseptatum, the reliable detection was achieved at the level of 10 and $100 \mathrm{pg}$ of genomic DNA (Lir1/Lir2 and Pau1/MaPa2, respectively) (Fig. 3).

Detection of $C$. liriodendri, $C$. macrodidymum, and $C$. pauciseptatum from in-

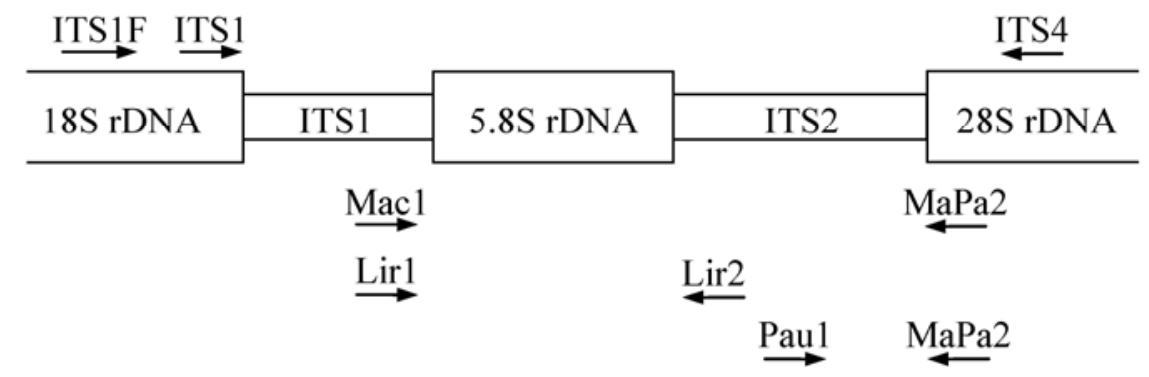

Fig. 1. Schematic representation of the internal transcribed spacer regions 1 and 2 and the 18S, 5.8S, and 28S ribosomal DNA showing the relative annealing sites of primer pairs Lir1/Lir2, Mac1/MaPa2, and Pau1/MaPa2 for the specific detection of Cylindrocarpon liriodendri, $C$. macrodidymum, and $C$. pauciseptatum, respectively, and the universal primers ITS1, ITS1F, and ITS4.

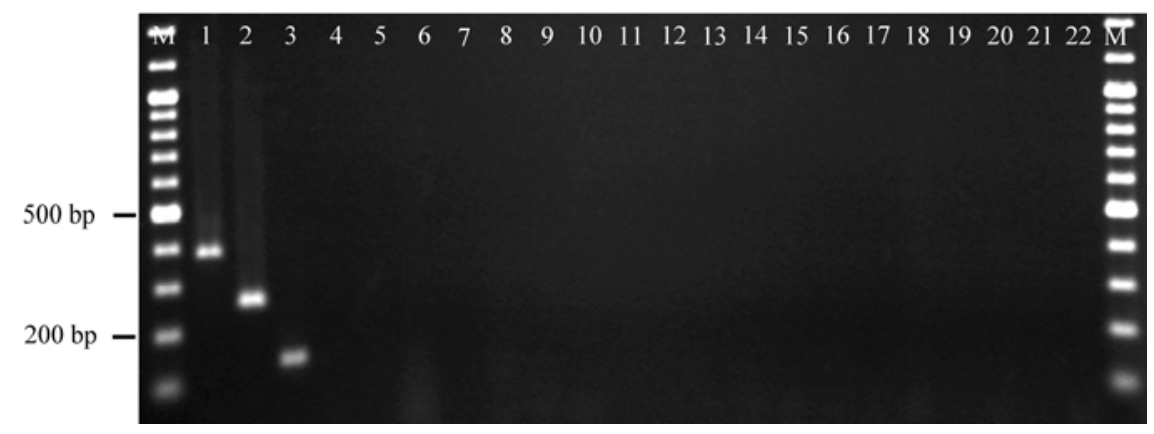

Fig. 2. Species-specific multiplex polymerase chain reaction amplification products generated with the three primer pairs, Mac1/MaPa2, Lir1/Lir2, and Pau1/MaPa2, for Cylindrocarpon macrodidymum (lane 1), C. liriodendri (lane 2), and C. pauciseptatum (lane 3). No product was amplified when using genomic DNA extracts of Campylocarpon fasciculare CBS 113554, Campylocarpon pseudofasciculare CBS 112679, Phaeomoniella chlamydospora, Phaeoacremonium aleophilum, P. inflatipes, P. mortoniae, P. parasiticum, P. scolyti, Diplodia seriata, Fusicoccum aesculi, Neofusicoccum parvum, Eutypa lata, Fomitiporia mediterranea, Stereum hirsutum, Alternaria alternata, Cladosporium sp., Fusarium oxysporum, and Penicillium digitatum (lanes 4 to 21). Lane 22, negative control; lanes M, 100-bp DNA ladder.

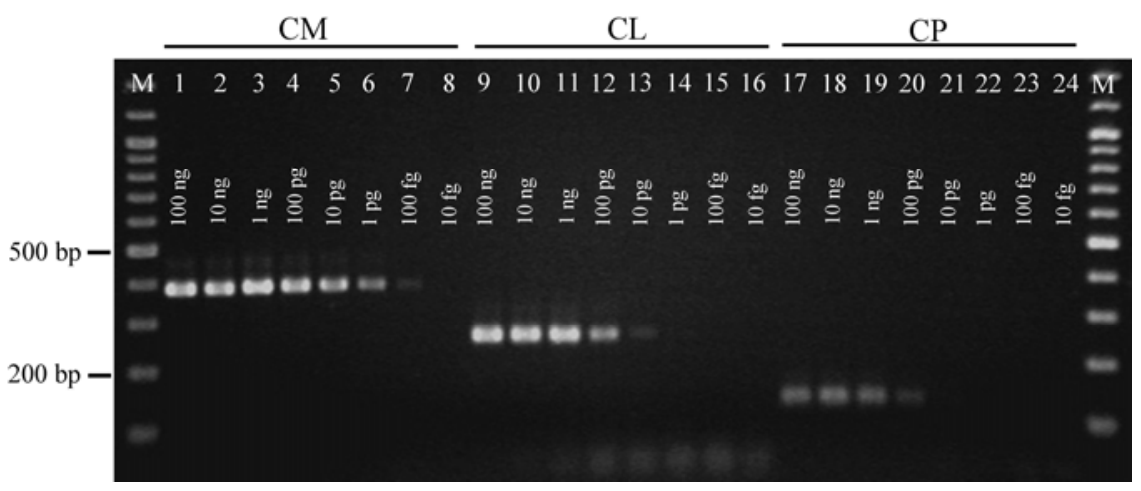

Fig. 3. Sensitivity of multiplex polymerase chain reaction amplification with species-specific primer pairs Mac1/MaPa2, Lir1/Lir2, and Pau1/MaPa2. A minimum of $100 \mathrm{fg}$ of genomic DNA was required for detecting Cylindrocarpon macrodidymum (CM; lanes 1 to 8), $10 \mathrm{pg}$ for C. liriodendri (CL; lanes 9 to 16 ), and $100 \mathrm{pg}$ for $C$. pauciseptatum (CP; lanes 17 to 24). Lanes M, 100-bp DNA ladder. 
oculated plants by nested PCR. C. liriodendri, C. macrodidymum, and C. pauciseptatum produced root necrotic lesions in all inoculated rootstock cuttings. The first round of amplification with DNA obtained from root lesions of artificially infected rootstock cuttings by using ITS1F/ITS4 primers resulted in 590-bp long PCR products. The second round of amplification performed with species-specific primers Lir1/Lir2, Mac1/MaPa2, and $\mathrm{Pau} 1 / \mathrm{MaPa} 2$ in a multiplex PCR specifically detected $C$. liriodendri, C. macrodidymum, or $C$. pauciseptatum from the amplified DNA obtained from each grapevine inoculated with $C$. liriodendri, $C$. macrodidymum, or $C$. pauciseptatum, respectively, generating the expected size bands in each species (Fig. 4). Cylindrocarpon DNA was never amplified from noninoculated grapevines in either of the two rounds of amplification.

\section{DISCUSSION}

This study developed a PCR-based method for the detection and identification of three Cylindrocarpon species associated with grapevine, C. liriodendri, C. macrodidymum, and $C$. pauciseptatum, from pure culture or infected grapevines. This method is a quick and easy species identification alternative to the long and inconclusive traditional characterization using phenotypical characters (2).

The set of three primer pairs designed in this work, Lir1/Lir2, Mac1/MaPa2, and
Pau1/MaPa2, clearly distinguished the three Cylindrocarpon species in a multiplex PCR assay. Moreover, using purified fungal template DNA, all three pairs of primers have proven to be sensitive to detect very low quantities of DNA. The quick DNA extraction method evaluated has proven to be efficient to obtain DNA from pure cultures of Cylindrocarpon spp. The multiplex PCR consistently yields amplicons with DNA obtained with both quick and traditional extraction methods. The use of a rapid method of DNA extraction allows completing a diagnosis in a short time and at low cost.

Additionally, a nested multiplex PCR was developed to detect $C$. liriodendri, $C$. macrodidymum, and $C$. pauciseptatum from grapevines. This method was able to detect $C$. liriodendri, C. macrodidymum, and $C$. pauciseptatum from artificially inoculated grapevine rootstock cuttings. The first round of amplifications performed with the universal fungal primers, ITS1F/ITS4, enriched the fungal rDNA in the plant genomic background, and the second round performed with the three specific primers pairs reached a selective amplification of the target pathogen.

Hamelin et al. previously developed a nested multiplex PCR with species-specific primers (Dest1/Dest4) for the detection of C. destructans and C. floridanum from naturally infected conifer nursery seedlings (14). Nascimento et al. evaluated these primers to detect $C$. destructans from
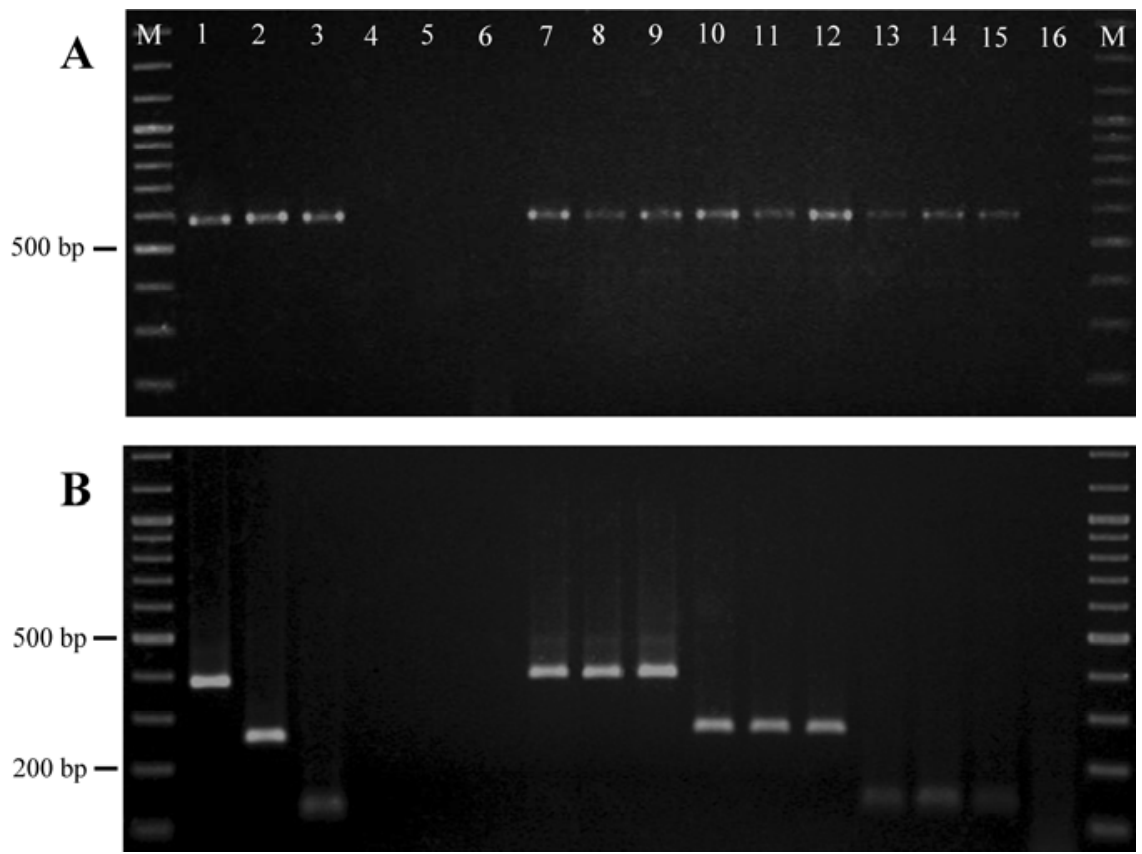

Fig. 4. Detection of Cylindrocarpon macrodidymum, C. liriodendri, and C. pauciseptatum from artificially infected grapevine roots by nested multiplex polymerase chain reaction (PCR). A, PCR amplification products generated with universal fungal primers ITS1F/ITS4 targeting total DNA extracts. B, Nested multiplex PCR amplification products with three primer pairs, Mac1/MaPa2, Lir1/Lir2, and Pau1/MaPa2, targeting the ITS1F/ITS4 products. Lanes 1 to 3, positive control (DNA from pure culture) of C. macrodidymum, C. liriodendri, and C. pauciseptatum, respectively; lanes 4 to 6 , noninoculated rootstock cuttings; lanes 7 to 9 , rootstock cuttings inoculated with C. macrodidymum; lanes 10 to 12 , rootstock cuttings inoculated with $C$. liriodendri; lanes 13 to 15 , rootstock cuttings inoculated with C. pauciseptatum; lane 16, negative control; lanes M, 100-bp DNA ladder. grapevine plants with DNA from pure cultures, but they amplified indistinctly $C$. destructans and C. obtusisporum (19). Dubrosky and Fabritius (6) designed a pair of primers to identify Cylindrocarpon from infected grapevines in nurseries, but these primers are genus specific and thus cannot distinguish species.

Alaniz et al. (1) indicated that $C$. liriodendri and $C$. macrodidymum isolates causing black foot disease of grapevine have different levels of virulence. In addition, in our work, $C$. pauciseptatum was able to produce root necrotic lesions in 110 $\mathrm{R}$ rootstock cuttings. Although further research is needed to confirm the role of $C$. pauciseptatum as a causal agent of black foot disease, the species-specific primers designed here can thus contribute to improving the management of black foot disease due to the reliable species identification

\section{ACKNOWLEDGMENTS}

Financial support is acknowledged from Projects AGL2006-11884-C04-01 (Ministerio de Educación y Ciencia, Spain) and RTA2007-00023-C04-03 (Programa Nacional de Recursos y Tecnologías Agrarias, Ministerio de Educación y Ciencia, Spain). Sandra Alaniz was supported by a grant from the Agencia Española de Cooperación Internacional (AECI-Ministerio de Asuntos Exteriores y Cooperación, Spain). We thank Cecilia Rego and H. J. Schroers for providing reference isolates. We also thank H. J. Schroers for reviewing the manuscript.

\section{LITERATURE CITED}

1. Alaniz, S., Armengol, J., León, M., GarcíaJiménez, J., and Abad-Campos, P. 2008 Analysis of genetic and virulence diversity of Cylindrocarpon liriodendri and C. macrodidymum associated with black foot disease of grapevine. Mycol. Res. 113:16-23.

2. Alaniz, S., León, M., Vicent, A., GarcíaJiménez, J., Abad-Campos, P., and Armengol, J. 2007. Characterization of Cylindrocarpon species associated with black foot disease of grapevine in Spain. Plant Dis. 91:1187-1193.

3. Collado-Romero, M., Mercado-Blanco, J Olivares-García, C., Valverde-Corredor, A. and Jiménez-Díaz, R. 2006. Molecular variability within and among Verticillium dahliae vegetative compatibility groups determined by fluorescent amplified fragment length polymorphism and polymerase chain reaction markers. Phytopathology 96:485-495.

4. Côté, M. J., Tardif, M. C., and Meldrum, A. J. 2004. Identification of Monilinia fructigena, $M$. fructicola, M. laxa, and $M$. polystroma on inoculated and naturally infected fruit using multiplex PCR. Plant Dis. 88:1219-1225.

5. Chamberlain, J. S., Gibbs, R. A., Ranier, J. Nguyen, P. N., and Caskey, T. 1988. Deletion screening of the Duchenne muscular dystrophy locus via multiplex DNA amplification. $\mathrm{Nu}-$ cleic Acids Res.16:11141-11156.

6. Dubrovsky, S., and Fabritius, A. L. 2007. Occurrence of Cylindrocarpon spp. in nursery grapevine in California. Phytopathol. Mediterr. 46:84-86.

7. Fisher, M., and Kassemeyer, H. H. 2003. Fungi associated with Esca disease of grapevine in Germany. Vitis 42:109-116.

8. Gardes, M., and Bruns, T. D. 1993. ITS primers with enhanced specificity for basiodiomycetes-applications to the identification of mycorrhizae and rusts. Mol. Ecol. 2:113-118.

9. Grasso, S. 1984. Infezioni di Fusarium 
oxysporum e di Cylindrocarpon destructans associate a una moria di giovani piante di vite in Sicilia. Inform. Fitopatol. 1:59-63.

10. Grasso, S. and Magnano Di San Lio, G. 1975. Infezioni di Cylindrocarpon obtusisporum su piante di vite in Sicilia. Vitis 14:38-39.

11. Halleen, F., Fourie, P. H., and Crous, P. W. 2006. A review of black foot disease of grapevine. Phytopathol. Mediterr. 45:S55-67.

12. Halleen, F., Schroers, H. J., Groenewald, J. Z., and Crous, P. W. 2004. Novel species of Cylindrocarpon (Neonectria) and Campylocarpon gen. nov. associated with black foot disease of grapevines (Vitis spp.). Stud. Mycol. 50:431455.

13. Halleen, F., Schroers H. J., Groenewald, J. Z., Rego, C., Oliveira, H., and Crous, P. W. 2006. Neonectria liriodendri sp. nov., the main causal agent of black foot disease of grapevine. Stud. Mycol. 55:227-234.

14. Hamelin, R. C., Bérubé, P., Gignac, M., and Bourassa, M. 1996. Identification of root rot fungi in nursery seedling by nested multiplex PCR. Appl. Environ. Microbiol. 62:40264031.

15. Hyun, J. W., Peres, N. A., Yi, S.-Y., Timmer, L. W., Kim, K. S., Kwon, H.-M., and Lim, H.-C. 2007. Development of PCR assays for the identifications of species and pathotypes of Elsinö causing scab on citrus. Plant Dis. 91:865-870.

16. Maluta, D. R., and Larignon, P. 1991. Pied-noir: Mieux vaut prévenir. Viticulture 11:71-72.

17. Malvárez, G., Rodríguez, A., Aguilar, C., Silveira, A. C., Silvera, E., Burgueño, J., and Mondino, P. 2004. Monilinia fructicola, única especie presente ocasionando la podredumbre morena del duraznero (Prunus persica) en Uruguay. Fitopatología 39:126-132.

18. Mishra, P. K., Fox, R. T., and Culham, A. 2003. Development of PCR-based assay for rapid and reliable identification of pathogenic Fusaria. FEMS Microbiol. Lett. 218:329-332.

19. Nascimento, T., Rego, C., and Oliveira, H. 2001. Detection of Cylindrocarpon black-foot pathogens in grapevine by nested PCR. Phytopathol. Mediterr. 40:S357-361.

20. Nieto-Feliner, G., and Rossello, J. A. 2007. Better the devil you know? Guidelines for insightful utilization of nrDNA ITS in specieslevel evolutionary studies in plants. Mol. Phylogenet. Evol. 44:911-919.

21. Peres, N. A., Harakava, R., Carroll, G. C., Adaskaveg, J. E., and Timmer, L. W. 2007. Comparison of molecular procedures for detection and identification of Guignardia citricarpa and G. mangiferae. Plant Dis. 91:525531.

22. Petit, E., and Gubler, W. D. 2005. Characterization of Cylindrocarpon species, the cause of black foot disease of grapevine in California. Plant Dis. 89:1051-1059.

23. Plyler, T. R., Simone, G. W., Fernandez, D., and Kistler, H. C. 1999. Rapid detection of the Fusarium oxysporum lineage containing the Canary Island date palm wilt pathogen. Phytopathology 89:407-413.

24. Rego, C., Nascimento, T., and Oliveira, H. 2001. Characterization of Cylindrocarpon destructans isolates from grapevines in Portugal. Phytopathol. Mediterr. 40:S343-350.

25. Rego, C., Oliveira, H., Carvalho, A., and
Phillips, A. 2000. Involvement of Phaeoacremonium spp. and Cylindrocarpon destructan with grapevine decline in Portugal. Phytopathol. Mediterr. 39:76-79.

26. Renker, C., Heinrichs, J., Kaldorf, M., and Buscot, F. 2003. Combining nested PCR and restriction digest of the internal transcribed spacer to characterize arbuscular mycorrhizal fungi on roots from the fields. Mycorrhiza 13:191-198.

27. Rumbos, I., and Rumbou, A. 2001. Fungi associated with esca and young grapevine decline in Greece. Phytopathol. Mediterr. 40:S330-335.

28. Scheck, H. J., Vasquez, S. J., and Gubler. W. D. 1998. First report of black-foot disease, caused by Cylindrocarpon obtusisporum, of grapevine in California. Plant Dis. 82:448.

29. Schroers, H. J., Žerjab, M., Munda, A., and Halleen, F. 2008. Cylindrocarpon pauciseptatum sp. nov., with notes on Cylindrocarpon species with wide, predominantly 3-septate macroconidia. Mycol. Res.112:82-92.

30. Thompson, J. D., Higgins, D. G., and Gibson T. J. 1994. CLUSTAL W: Improving the sensitivity of progressive multiple sequence alignment through sequence weighting, position-specific gap penalties and weight matrix choice. Nucleic Acids Res. 22:4673-4680.

31. White, T. J., Bruns, T., Lee, S., and Taylor, J. W. 1990. Amplification and direct sequencing of fungal ribosomal RNA genes for phylogenetic. Pages 315-322 in: PCR Protocols, A Guide to Methods and Applications. M. A. In nis, D. H. Gelfand, J. J. Sninsky, and T. J. White, eds. Academics Press. San Diego. CA. 